\title{
KEBARUAN DAN PEMBAHARUAN HUKUM PERCEPATAN EKONOMI DIGITAL DESA DALAM BINGKAI NEGARA HUKUM
}

\section{Sarip}

Fakultas Hukum Universitas Muhammadiyah Cirebon

Jl. Tuparev No. 70, Cirebon Kode Pos: 45153, Telp: 082130446632, email: sarip@umc.ac.id

\begin{abstract}
Abstrak
Kebaruan teknologi bagi masyarakat desa merupakan keadaan yang harus segera diimbangi oleh pembaharuan hukum. Program percepatan desa merupakan kebaruan apabila tidak diperhatikan ibarat merusak slaput dara perempuan. Melalui penelusuran kepustakaan menjadikan penelitian hukum ini bersifat normatif. Hasilnya pemerintah melihat kebaruan teknologi dan melakukan pembaharuan hukum. Pembahasan melihat kebaruan dan pembaharuan hukum dari sisi rekayasa sosial, kemudian dilakukan kontruksi dimana agar pembaharuan hukum tidak merusak tatanan masyarakat desa. Desa ibarat slaput dara perempuan maka untuk melakukan pembaharuan hukum dan merekayasa masyarakat harus berhati-hati.
\end{abstract}

Kata kunci: Kebaruan, Pembaharuan, rekayasa, desa

\section{A.Pendahuluan}

Soekarno pada Sidang BPUPKI tanggal 1 Juni 1945, ungkapan itu berbunyi: "Rakyat ingin sejahtera. Rakyat, yang tadinya merasa dirinya kurang makan, pakaian, mencitakan dunia baru yang di dalamnya ada keadilan, di bawah pimpinan Ratu Adil. ${ }^{1}$ Maka oleh karena itu, jikalau memang betul-betul mangerti, mengingat, mencintai rakyat Indonesia, marilah kita terima prinsip hal sociale rechtvaardigheid, yaitu bukan saja

\footnotetext{
${ }^{1}$ Sartono Kartodirdjo, (1984), Ratu Adil, Jakarta: Sinar Harapan, hlm. 9-10.
}

persamaan, artinya kesejahteraan bersamasama yang sebaik-baiknya".2

Kebaruan dan pembaharuan hukum desa dalam rangka percepatan ekonomi digital merupakan saluran, sarana, sejenis selaput yang bisa ditembus tanpa mengganggu atau merusak selaput. ${ }^{3}$

2 Azhari, Negara Hukum Indonesia, Analisis Normatif Tentang Unsur-Unsurnya, Universitas Indonesia Press, (Jakarta: 1995), 166. Lihat juga Sayuti, "Konsep Rechts Staat dalam Negara Hukum Indonesia (Analisis Terhadap Pendapat Azhari)", Jurnal Kajian Ekonomi Islam dan Kemasyarakatan NALAR FIQH, Volume 4. Nomor 2. 2011, 81-105.

3 Bandingkan dengan Lawrence F. Friedman, (Terjemahan), (1998), The Legal System A Social 
Sebagai ilutrasi dapat digambarkan beberapa bentuk selaput dara yang dimiliki oleh perempuan, bentuk selaput dara dan salah satu selaput dara (hymen) ada yang bersifat elastis. ${ }^{4}$ Walaupun telah beberapa kali mengadakan hubungan intim selaput tersebut tetap utuh. Bahkan hal yang mengejutkan ketika terjadi peristiwa pemerkosaan selaput dara yang demikian tidak mengalami kerusakan sebagaimana dibuktikan dalam hasil test kehamilan yang dilakukan oleh dokter atau media (visum et revertum)..$^{5}$ Kemudian sangat aneh ketika sang perempuan dinyatakan hamil oleh dokter. Fenomena seperti inilah yang harus di jawab dengan penuh akal sehat, begitu juga dengan percepatan ekonomi digital.

Jika diperhatikan dari gambaran tersebut akan ada suatu paradigma baru sebelum mengambil suatu tindakan untuk melanjutkan atau menghentikan kebaruan dan pembaharuan hukum di era digital, adanya argumentasi-argumentasi yang

Science Persepective, Russel Sage Foundation, New York:, hlm.205.

${ }^{4}$ Lebih jelas tentang slaput dara (Purwanto PS dan Norman Heryandi, Aspek Medikolegal Pemeriksaan Selaput Dara Pada Korban Dugaan Perkosaan di RS. Dr. Hasan Sadikin Bandung, Perhimpunan Dokter Forensik Indonesia, Proseding Pertemuan Tahunan di Pekanbaru tanggal 15-16 Juli Tahun 2017.

5 Visum sendiri diartikan tanda pernyataan atau keterangan telah mengetahui atau menyetujui, https://kbbi.web.id/visum, Up Date 2 Mei 2018. dapat diterima secara umum.

Kecenderungan melebih-lebihkan akan hal yang dianggap baru sebagai suatu kaharusan dan hanya dilihat dari sisi fomal belaka. ${ }^{6}$ Bahkan, ada yang mengatakan bahwa dorongan untuk percepatan ekonomi digital telah melalui pengkajian yang mendalam dan matang. Namun, kematangan perkataan tidak dipraktikan dalam keadaan yang riil di desa-desa. Misalnya masih rendahnya masyarakat dalam bidang digital.

Paham negara hukum berdasarkan keyakinan bahwa kekuasaan harus dijalankan atas dasar hukum yang baik dan adil. Menurut Franz Maginis Suseno ada dua unsur dalam negara hukum, yakni: ${ }^{7}$

1. Hubungan antara yang memerintah dan yang diperintah tidak berdasarkan kekuasaan melainkan berdasarkan suatu norma yang objektif yang juga mengikat yang memerintah;

2. Bahwa norma objektif itu, hukum memenuhi syarat bukan hanya formal, melainkan dapat dipertahankan berhadapan dengan ide hukum, hukum

\footnotetext{
${ }^{6}$ Sisis formal yang dimaksudkan hanya mengacu pada peluang yang terdapat dalam peraturan perundang-undangan yakni UU No.32 tahun 2004 tentang Pemerintahan Daerah yang menggantikan UU No.22 tahun 1999.

7 Franz Maginis Suseno dalam Teguh Prasetyo "Rule of Law dalam Dimensi Negara Hukum Indonesia", Jurnal Ilmu Hukum REFLEKSI Hukum, Edisi Oktober, 2010, hlm. 130.
}

Volume 2 No.1 April 2018

ISSN Cetak: 2579-9983, E-ISSN: 2579-6380

Halaman. 1-17 
menjadi landasan segenap negara dan hukum itu sendiri harus baik dan adil, baik karena sesuai dengan apa yang diharapkan hukum, adil karena segenap hukum adalah keadilan.

3. Bila suatu keputusan atau kebijakan penguasa dinilai merugikan dan keliru maka keputusan tersebut akan ditentang, sebaliknya bila kebijaksanaan itu menguntungkan dan tepat, maka kepatuhan akan diberikan. ${ }^{8}$

Jadi pada dasarnya, tulisan yang disajikan bukanlah suatu penolakan ataupun penerimaan terhadap itikad baik pemerintah. Melainkan lebih menekankan pada kesiapan-kesiapan yang harus dibenahi terlebih dahulu sebelum mengambil tindakan yang penuh risiko. Sebab bagi penulis tidak menginginkan ada argumentasi yang sumir terhadap mereka yang medukung maupun yang menolak percepatan perekonomian digital. Sisi keterbukaan publik desa sudah mulai terbangun, patut juga untuk diapresiasi. Namun, yang menjadi pertanyaan sekarang yakni bagaimana kebaruan dan pembaharuan hukum melihat keadaan percepatan ekonomi di desa dilihat dari negara hukum.

\footnotetext{
${ }^{8}$ Apcil Carter, Otoritas dan Demokrasi, Rajawali Press, (Jakarta: 1985), hlm xvi
}

\section{B. Metode Penelitian}

Metode yang digunakan yakni dilakukan dengan cara mencari informasi melalui berbagai sumber bacaan baik yang berupa buku, jurnal, dan berita di internet.

Melalui penelusuran literatur diharapkan dapat menemukan benang merah dan mendapatkan titik terang tentang kebaruan dan pembaharuan hukum di bidang percepatan ekonomi di desa antara kemajuan dan tantangan globalisasi yang ada.

Jenis penelitian sendiri menggunakan penelitian kualitatif deskriptif, dilakukan dengan cara mendeskripsikan pemikiran yang berkenaan dengan pokok bahasan. ${ }^{9}$ Kemudian melakukan analisis hukum normatif melalui aturan-aturan hukum formal yang dinilai mendiskriminasikan dan mendukung percepatan ekonomi di desa kemudian mencoba menarik simpulan yang sesuai dengan rumusan masalah yang telah disajikan.

\section{Pembahasan}

Fakta Kebaruan Percepatan Ekonomi Desa dan Lembaga Negara Untuk Percepatan Ekonomi

\footnotetext{
${ }^{9}$ http://file.upi.edu/Direktori/FIP/JUR._KURIKUL UM_DAN_TEK._PENDIDIKAN/1966101919910 21-RUDI_SUSILANA/PM3-ModulPenelitian_5.pdf, Up Date 2 Mei 2018
} 
Kata "desa" tersebut kemudian dalam bahasa Jawa dipelintir menjadi kata "ndeso" untuk menyebut orang-orang atau penduduk yang berada di "udik" atau “pedalaman"atau yang punya sifat "kampung(an)". 10 Dalam kamus Besar Bahasa Indonesia kata "desa" diartikan sebagai kesatuan wilayah yang dihuni oleh sejumlah keluarga yang memunyai system pemerintahan sendiri. ${ }^{11}$ Keberadaan desa sebagai satu kesatuan masyarakat hukum member pemahaman yang mendalam bahwa institusi desa bukan hanya sebagai entitas administratif belaka tetapi juga entitas hukum yang harus dihargai, diistimewakan, dilestarikan, dan dilindungi dalam struktur pemerintahan di Indonesia.

Hal ini yang kemudian tertuang dalam UUD 1945 pasal 18 B ayat (2) yang menyatakan: "Negara mengakui dan menghormati kesatuan-kesatuan masyarakat hukum adat beserta hak-hak tradisionalnya sepanjang masih hidup dan sesuai dengan perkembangan masyarakat dan prinsip Negara Kesatuan Republik

10 Titik Triwulan Tutik, Pokok-pokok Hukum Tata Negara, Prestasi Pustaka (Jakarta:, 2006), 3 , Bandingkan dengan Eko Endarmoko, Tesaurus Bahasa Indonesia dalam Moh. Fadli dk, Pembentukan Peraturan Desa Partisipatif, Brawijaya Press, (Malang: 2011), 3.

11 Tim Penyusun kamus Pusat Pembianaan dan Pengembangan Bahasa, Kamus Besar Bahasa Indonesia Cet. VII, Balai Pustaka, (Jakarta: 1995), 226.
Indonesia, yang diatur denganundangundang". Berdasarkan bunyi Pasal 18 B ayat (2) UUD 1945 tersebut maka desa diartikan bukan saja sebagai kesatuan masyarakat hukum adat, tetapi juga sebagai hierarki pemerintahan yang terendah dalam NKR. ${ }^{12}$ Walaupun semuanya wajib menjadi catatan bahwa tidak semua desa dapat dikatakan sebagai masyarakat kesatuan hukum adat. Sebagaimana bunyi Desa adalah kesatuan masyarakat hukum yang memiliki batas wilayah yang berwenang untuk mengatur dan mengurus urusan pemerintahan, kepentingan masyarakat setempat berdasarkan prakarsa masyarakat, hak asal usul, dan/atau hak tradisional yang diakui dan dihormati dalam sistem pemerintahan Negara Kesatuan Republik Indonesia. ${ }^{13}$

Sistem ekonomi Indonesia bergerak ke arah baru, konsumen menjadi titik sentral produksi, penggunaan teknologi di segala bidang, kemudahan akses informasi yang kian transparan, bentuk-bentuk aliansi strategis dan kerjasama antar

\footnotetext{
${ }^{12}$ Khairuddin Tahmid, Dekonstruksi Politik Hukum Otonomi Desa Dalam Peraturan Perundangundangan Di Indonesia, (Yogyakarta: ringkasan disertasi progam doktor UII, 2011), 3. Lihat dalam Yusnani Hasyimzoem, "Dinamika Hukum Pemerintahan Desa", Jurnal Fiat Justitia Ilmu Hukum, Volume 8, Nomor 5, 2014, 464.

${ }^{13}$ Undang-Undang Nomor 6 Tahun 2014 tentang Desa Pasal 1 Ayat 1 Lembaran Negara Nomor 7 dan Tambahan Lembaran Negara Nomor 5495.
} 
perusahaan (bahkan antar negara) membentangkan jalan bagi ekonomi untuk memperoleh tempat yang baru. Beberapa orang menyebutnya Ekonomi Baru (New Economy). Ada pula yang menyebutnya Ekonomi Digital (Digital Economy), Ekonomi Internet (Internet Economy) ataupun Ekonomi Jaring (Web Economy). ${ }^{14}$ Hal ini menandakan perubahan yang harus diimbangi oleh hukum nasional yang berlaku sampai kedesa-desa yang ada di Indonesia.

Website desa merupakan salah satu sasaran program Kementrian Komunikasi dan Informatika (Menkominfo) memberikan Website gratis satu tahun dengan domain berekstensi.id sampai tahun 2019. ${ }^{15}$ Tujuannya membantu para pengusaha untuk memasarkan produknya melalui internet. Pendampingan sampai saat ini baru tersedia untuk Jawa Barat, Jawa Tengah, Jawa Timur, dan Daerah Istimewa Yogyakarta, propinsi lainnya akan segera menyusul. Sejak tahun 2014 pemerintah melakukan terobosan dengan program 1.000 website desa, merupakan strategi mengarusutamakan isu-isu

\footnotetext{
${ }^{14}$ C.T. Adhikara, Siapa Konsumen Kita?: Analisis Perubahan Konsumen di Era Ekonomi Baru, Jurnal The WINNER, Volume. 6 No.2, September 2005, hlm 176-183.

${ }^{15}$ http://bpmpd.ntprov.go.id/index.php/2016/08/03/ website-gratis-1-tahun-dari-kementrian-kominfo/ Up Date 29 Januari 2018.
}

perdesaan di ruang publik. Tujuannya mempengaruhi kebijakan publik, produk dan potensi di desa, meningkatkan perekonomian masyarakat. Program website desa sampai sekarang masih terus berjalan, terobosan pemerintah untuk mengurangi kesenjangan informasi di desa.

Terobosan yang dilakukan pemerintah berbanding lurus dengan bantuan pemerintah di bidang keuangan terhadap desa. Mendagri mencatat tahun 2015 jumlah desa 74.053 tersebar diseluruh Indonesia. Kemendes mencatat 701 desa baru di tahun 2016 menjadi 74.754 desa. Tahun 2017 penambahan 200 desa menjadi 74.954. Jumlah penduduk Indonesia yang tinggal di desa sekitar $45 \%$ (112,5\% juta jiwa) dari total penduduk Indonesia. Jumlah peningkatan desa terjadi dalam kurun waktu 2016 dan 2017 merupakan hasil pemekaran desa. ${ }^{16}$ Pemekaran desa dalam kurun waktu dua tahun terakhir, tidak menyurutkan pemerintah dalam memberikan dana desa. Bukti nyata setiap desa pada tahun 2015 sebesar Rp. 750 juta, tahun 2016 meningkat menjadi Rp. 800 juta, tahun 2017 mencapai Rp. 1 miliyar-Rp. 1,4 miliyar.

16 Kemendes, Petunjuk Teknis Lomba Penulisan Artikel Dana Desa Tahun 2018, hlm 1.

Volume 2 No.1 April 2018

ISSN Cetak: 2579-9983, E-ISSN: 2579-6380

Halaman. 1-17 
Terobosan pemerintah membuka ruang publik di desa untuk mendukung, mengawasi, serta berpartisipasi untuk kemajuan desa. Program 1.000 website desa mengalami kendala, masyarakat desa sekitar $70 \%$ berpendidikan dasar, kurang mampu menggunakan program website desa secara maksimal. ${ }^{17}$ Tahun 2017 pemaksimalan website desa sudah mengalami kemajuan, tidak terlepas dari pendidikan masyarakat mulai terbuka. Hasil di tahun 2017 website desa mulai dipenuhi tulisan-tulisan kemajuan desa, kejadian di desa, sampai upacara adat desa.

Berdasarkan Putusan Mahkamah Konstitusi Nomor 20/PUU-XIV/2016, Mahkamah Konstitusi berpendapat bahwa untuk mencegah terjadinya perbedaan penafsiran terhadap Pasal 5 ayat (1) dan ayat (2) UU ITE, Mahkamah menegaskan bahwa setiap intersepsi harus dilakukan secara sah, terlebih lagi dalam rangka penegakan hukum. Oleh karena itu, Mahkamah dalam amar putusannya menambahkan kata atau frasa "khususnya" terhadap frasa "Informasi Elektronik dan/atau Dokumen Elektronik". Agar tidak terjadi penafsiran bahwa putusan tersebut akan mempersempit makna atau arti yang terdapat di dalam Pasal 5 ayat (1) dan ayat

\footnotetext{
${ }^{17}$ Data Dinas Pendidikan Kabupaten Cirebon 2016.
}

(2) UU ITE, untuk memberikan kepastian hukum keberadaan Informasi Elektronik dan/atau Dokumen Elektronik sebagai alat bukti perlu dipertegas kembali dalam Penjelasan Pasal 5 UU ITE.

Ketentuan mengenai penggeledahan, penyitaan, penangkapan, dan penahanan yang diatur dalam UU ITE menimbulkan permasalahan bagi penyidik karena tindak pidana di bidang Teknologi Informasi dan Transaksi Elektronik begitu cepat dan pelaku dapat dengan mudah mengaburkan perbuatan atau alat bukti kejahatan. Ketiga, karakteristik virtualitas ruang siber memungkinkan konten ilegal seperti Informasi dan/atau Dokumen Elektronik yang memiliki muatan yang melanggar kesusilaan, perjudian, penghinaan atau pencemaran nama baik, pemerasan dan/atau pengancaman, penyebaran berita bohong dan menyesatkan sehingga mengakibatkan kerugian konsumen dalam Transaksi Elektronik, serta perbuatan menyebarkan kebencian atau permusuhan berdasarkan suku, agama, ras, dan golongan, dan pengiriman ancaman kekerasan atau menakut-nakuti yang ditujukan secara pribadi dapat diakses, didistribusikan, ditransmisikan, disalin, disimpan untuk didiseminasi kembali dari mana saja dan kapan saja.

6 
Dalam rangka melindungi kepentingan umum dari segala jenis gangguan sebagai akibat penyalahgunaan Informasi Elektronik dan Transaksi Elektronik, diperlukan penegasan peran Pemerintah dalam mencegah penyebarluasan konten illegal dengan melakukan tindakan pemutusan akses terhadap Informasi Elektronik dan/atau Dokumen Elektronik yang memiliki muatan yang melanggar hukum agar tidak dapat diakses dari yurisdiksi Indonesia serta dibutuhkan kewenangan bagi penyidik untuk meminta informasi yang terdapat dalam Penyelenggara Sistem Elektronik untuk kepentingan penegakan hukum tindak pidana di bidang Teknologi Informasi dan Transaksi Elektronik.

Penggunaan setiap informasi melalui media atau Sistem Elektronik yang menyangkut data pribadi seseorang harus dilakukan atas persetujuan Orang yang bersangkutan. Untuk itu, dibutuhkan jaminan pemenuhan perlindungan diri pribadi dengan mewajibkan setiap Penyelenggara Sistem Elektronik untuk menghapus Informasi Elektronik dan/atau Dokumen Elektronik yang tidak relevan yang berada di bawah kendalinya atas permintaan Orang yang bersangkutan berdasarkan penetapan pengadilan.
Berdasarkan pertimbangan tersebut, perlu membentuk Undang-Undang tentang Perubahan atas Undang-Undang Nomor 11 Tahun 2008 tentang Informasi dan Transaksi Elektronik (UU ITE) yang menegaskan kembali ketentuan keberadaan Informasi Elektronik dan/atau Dokumen Elektronik dalam Penjelasan Pasal 5, menambah ketentuan kewajiban penghapusan Informasi Elektronik dan/atau Dokumen Elektronik yang tidak relevan dalam Pasal 26, mengubah ketentuan Pasal 31 ayat (4) mengenai pendelegasian penyusunan tata cara intersepsi ke dalam undang-undang, menambah peran Pemerintah dalam melakukan pencegahan penyebarluasan dan penggunaan Informasi Elektronik dan/atau Dokumen Elektronik yang memiliki muatan yang dilarang dalam Pasal 40, mengubah beberapa ketentuan mengenai penyidikan yang terkait dengan dugaan tindak pidana di bidang Teknologi Informasi dan Transaksi Elektronik dalam Pasal 43, dan menambah penjelasan Pasal 27 ayat (1), ayat (3), dan ayat (4) agar lebih harmonis dengan sistem hukum pidana materiil yang diatur di Indonesia. Kebaruan dan pembaharuan Hukum Praksisnya Dalam Bidang Percepatan Ekonomi Masyarakat Desa 
Masih ada perbedaan pendapat cukup tajam di antara kita tentang konsep Ilmu Hukum. Perbedaan terjadi karena kita tidak bertolak dari kerangka analitis yang disepakati bersama sebagai prapemahaman untuk konsep Ilmu Hukum, sehingga perbedaan yang terjadi lebih karena soal pilihan selera intelektual masing-masing pribadi. ${ }^{18}$

Pernyataan Roscoe Pound tersebut pada awal orde baru dibawa ke Indonesia oleh pakar-pakar hukum saat itu dengan pemikiran bahwa hukum merupakan alat rekayasa sosial. Dalam sistem hukum sipil (civil law system) yang diterapkan di Indonesia, yang menganut model hukum Eropa, hukum adalah sebuah aturan Undang-undang yang notabene merupakan produk kekuasaan penguasa. $^{19}$ Dalam konteks ini, maka hukum diterapkan oleh penguasa yang memiliki kewenangan membentuk hukum, dan demi hukum siapapun harus tunduk terhadap aturan hukum tersebut.

18 Krishna Djaya Darumurti, "Karakter Ilmu Hukum: Pendekatan Fungsional Dalam Kaitan dengan Pendidikan Hukum". Jurnal REFLEKSI HUKUM, Volume 1, Nomor 2, 2016, 191-212.

19 Lihat Sarip, Pola Pikir Kelas Elit Dalam Perumusan Perundang-Undangan di Indonesia, Jurnal De Jure Muhammadiyah Cirebon Volume 1, Nomor 1, 2017, 44. Lihat juga Fokky Fuad dalam, http://uai.ac.id/2011/04/13/hukum-sebagairekayasa-sosial-kesalahan-pemahaman-ataspemikiran-roscoe-pound/ Up date 20 Januari 2018
Bagi masyarakat desa website dapat dikatakan sebagai hal yang baru, apalagi memanfaatkan website desa untuk percepatan ekonomi desa. Dilihat dari sudut pandang hukum adanya website desa dapat dikatakan sebagai proses pabaharuan hukum atau dengan istilah lain sering menggunakannya dengan politik hukum. ${ }^{20}$ Penulis sengaja menggunakan istilah pembaharuan hukum, memiliki alasan tersendiri, dimana orang desa ketika bicara politik identik dengan partai politik.

Maka, istilah pembaharuan ini dirasakan tepat digunakan untuk tataran masyarakat desa. Antara kebaruan ${ }^{21}$ dan pembahruan hukum digunakan untuk melihat perubahan di desa berkenaan dengan perubahan masyarakat yang akan diarahkan pada percepatan ekonomi digital.

Untuk dapat memastikan mengenai adanya hubungan hukum dan perubahan sosial perlu memperhatikan bagaimana hukum berkenaan dengan masyarakat. Fungsi hukum salah satunya sebagai alat

\footnotetext{
${ }^{20}$ Bandingkan dengan istilah yang digunakan Moh. Mahfud MD. Politik Hukum di Indonesia. RajaGrafindo Persada, (Jakarta:2014).

21 Kebaruan sendiri merupakan kata benda terhadap sesuatu yang sebelaumnya belum ada, kata sifatnya yakni baru sesuatu yang belum ada. http://kbbi.kata.web.id/?s=baru, up date 21 Januari 2017.
} 
rekayasa sosial. ${ }^{22}$ Program website desa dapat dikatakan sebagai the law sosial engineering (hukum sebagai rekayasa sosial). Masyarakat desa coba direkayasa pemerintah melalui website desa, garis besarnya fungsi hukum yang berkenaan dengan program website desa merupakan saran untuk mengendalikan masyarakat desa akan nilai-nilai penting website desa terutama yang menjadi tujuan yakni percepatan ekonomi digital.

Perubahan sosial masyarakat desa yang dilakukan melalui website desa akan berpengaruh terhadap bekerjannya mekanisme pengendalian percepatan ekonomi digital. Sebab, timbul perubahan sosial secara subtansial di desa-desa dengan adanya website desa. Sebagai gambaran disaat terjadi peralihan dari transaksi manual di desa-desa melalui website desa, mengalami perubahan yang fundamental dalam hal transaksi perdagangan. Kalau semula transaksi mengahdirkan orang-orang sekarang transaksi tidak lagi demikian. Maka untuk mengantisipasi hal tersebut diperlukan the law sosial engineering dalam hal:

1. Proses adaptasi, meliputi ekonomi penggunaan teknologi dan ilmu

\footnotetext{
${ }^{22}$ Satjipto Rahardjo, Pemanfaatan Ilmu-Ilmu Sosial Bagi Pengembangan Ilmu Hukum, GentaPublishing, (Yogyakarta: 2010), 123.
}

pengetahuan yang tepat bagi masyarakat desa;

2. Proses penerapan tujuan/pengambilan keputusan yang tepat dari pemangku kebijakan agar tidak merugikan masyarakat desa;

3. Proses mempertahankan masyarakat yang dilakukan dengan cara sosialisasi akan nilai penting proses percepatan ekonomi digital;

4. Proses integrasi yang dilakukan oleh hukum dalam hal kebaruan dan pembaharuan hukum di bidang percepatan ekonomi digital. $^{23}$

Kebaruan dan pembaharuan hukum di bidang percepatan ekonomi digital merupakan kemerdekaan menyatakan pikiran dan kebebasan berpendapat serta hak memperoleh informasi melalui penggunaan dan pemanfaatan teknologi Informasi dan komunikasi ditujukan untuk:

1. Memajukan kesejahteraan umum;

2. Mencerdaskan kehidupan bangsa;

3. Memberikan rasa aman;

4. Keadilan; dan

5. Kepastian hukum bagi pengguna dan penyelenggara sistem elektronik.

Kehidupan bermasyarakat, berbangsa, dan bernegara, hak dan

23 Bandingkan dengan Talcott Parson dalam Satjipto Rahardjo, Pemanfaatan..., Ibid, 126.

Volume 2 No.1 April 2018

ISSN Cetak: 2579-9983, E-ISSN: 2579-6380

Halaman. 1-17 
kebebasan melalui penggunaan dan pemanfaatan Teknologi Informasi tersebut dilakukan dengan mempertimbangkan pembatasan yang ditetapkan dengan undang-undang dengan maksud sematamata untuk menjamin pengakuan serta penghormatan atas hak dan kebebasan orang lain dan untuk memenuhi tuntutan yang adil sesuai dengan pertimbangan moral, nilai-nilai agama, keamanan, dan ketertiban umum dalam suatu masyarakat demokratis. $^{24}$

UU ITE merupakan hal kebaruan undang-undang pertama di bidang Teknologi Informasi dan Transaksi Elektronik sebagai produk legislasi yang sangat dibutuhkan dan telah menjadi pionir yang meletakkan dasar pengaturan di bidang pemanfaatan Teknologi Informasi dan Transaksi Elektronik. ${ }^{25}$ Namun, pembaharuan muncul berdasarkan Putusan Mahkamah Konstitusi Nomor 50/PUUVI/2008 dan Nomor 2/PUU-VII/2009,

\footnotetext{
${ }^{24}$ Lihat Penjelasan atas Undang-Undang Republik Indonesia Nomor 19 Tahun 2016 tentang Perubahan Atas Undang-Undang Nomor 11 Tahun 2008 tentang Informasi dan Transaksi Elektronik.

25 Akan tetapi, dalam kenyataannya, perjalanan implementasi dari UU ITE mengalami persoalanpersoalan. Pertama, terhadap Undang-Undang ini telah diajukan beberapa kali uji materiildi Mahkamah Konstitusi dengan Putusan Mahkamah Konstitusi Nomor 50/PUU-VI/2008, Nomor 2/PUU-VII/2009, Nomor 5/PUU-VIII/2010, dan Nomor 20/PUU-XIV/2016.
}

dimana tindak pidana penghinaan dan pencemaran nama baik dalam bidang Informasi Elektronik dan Transaksi Elektronik bukan semata-mata sebagai tindak pidana umum, melainkan sebagai delik aduan. Penegasan mengenai delik aduan dimaksudkan agar selaras dengan asas kepastian hukum dan rasa keadilan masyarakat. The law social engineering merupakan alat yang digunakan untuk menggiring masyarakat mematuhi akan pembaharuan hukum termasuk didalamnya masyarakat desa.

Berdasarkan Putusan Mahkamah Konstitusi Nomor 5/PUU-VIII/2010, Mahkamah Konstitusi berpendapat bahwa kegiatan dan kewenangan penyadapan merupakan hal yang sangat sensitif karena di satu sisi merupakan pembatasan hak asasi manusia, tetapi di sisi lain memiliki aspek kepentingan hukum. Oleh karena itu, pengaturan (regulation) mengenai legalitas penyadapan harus dibentuk dan diformulasikan secara tepat sesuai dengan Undang-Undang Dasar Negara Republik Indonesia Tahun 1945.

Di samping itu, Mahkamah berpendapat bahwa karena penyadapan merupakan pelanggaran atas hak asasi manusia sebagaimana ditegaskan dalam Pasal 28J ayat (2) Undang-Undang Dasar Negara Republik Indonesia Tahun 1945, 
sangat wajar dan sudah sepatutnya jika negara ingin menyimpangi hak privasi warga negara tersebut, negara haruslah menyimpanginya dalam bentuk undangundang dan bukan dalam bentuk peraturan pemerintah.

Kebaruan dan Pembaharuan Hukum dalam Negara Hukum

Ide negara hukum rechtsstaat sesungguhnya sejak lama telah dikembangkan oleh para filosuf Yunani Kuno yang pada dasarnya bertumpu pada sistem hukum Eropa Kontinental yang mulai populer pada abad ke-17 karena pada saat itu situasi dan kondisi sosial politik di Eropa didominasi oleh absulutisme. Ide negara hukum rechtsstaat ini sesungguhnya dipelopori oleh Immanuel Kant dan Frederich Julius Stahl. Kant memahami negara hukum itu sebagai negara penjaga malam (nachtwakersstaat). Artinya, negara itu bertugas untuk menjaga ketertiban dan keamanan masyarakat. Pada awalnya Plato berpendapat bahwa adalah mungkin mewujudkan negara edial untuk mencapai kebaikan yang berintikan kebaikan. $^{26}$ Karena itu, kekuasaan harus dipegang oleh orang yang mengetahui kebaikan, yaitu

26 Sarip, Hukum Tata Negara Materil, Elsi Pro, (Cirebon: 2018), 33. seorang filosof (the philosopher king). Pada kesempatan lain Plato juga menyatakan bahwa yang dapat diwujudkan adalah bentuk paling baik kedua (the second best) yang menempatkan supremasi hukum. Pemerintahan yang mampu mencegak kekemerosotan kekuasaan seseorang adalah pemerintahan oleh hukum. Plato tujuan negara menurut Aristoteles adalah untuk mencapai kehidupan paling baik the best life possible) yang dapat dicapai dengan supremasi hukum. ${ }^{27}$ Sejak Plato menulis "Nomoi," E. Kant memaparkan prinsipprinsip negara hukum (formil). J. Stahl mengetengahkan negara hukum (materil), Descey mengajukan "Rule of law".

Ringkasnya, merupakan suatu negara yang edial pada abad ke-20 ini, jika segala kegiatan kenegaraan didasarkan pada hukum. ${ }^{28}$ Dalam pandangan Padmo Wahyono, pengisian pengertian tersebut selalu berkembang sesuai dengan tingkat kecerdasan suatu bangsa. Oleh karena itu, Padmo Wahyono berpegang pada perumusan sebagaimana yang digariskan

\footnotetext{
27 Jimly Asshiddiqie, Hukum Tata Negara dan Pilar-Pilar Pilar Demokrasi, Serpihan Pemikiran Hukum, Media dan HAM, Konstitusi Perss, (Jakarta:2006), 129

28 Padmo Wahyono, Pidato Pengukuhan sebagai Guru Besar Fakultas Hukum UI tanngal 17 November 1979. Seperti dikutip dalam bukunya sendiri, Indonesia Negara berdasarkan Atas Hukum, Ghalia Indonesia, (Jakarta: 1986), 7.
} 
oleh pembentuk Undang-Undang Dasar, yaitu, Indonesia ialah negara yang berdasarkan atas hukum, dengan rumusan "Reschtaas" dengan anggapan bahwa pola yang diambil tidak menyimpang dari pengertian negara hukum pada umumnya yang disesuaikan dengan keadaan Indonesia. Artinya digunakan dengan ukuran pandangan hidup maupun pandangan bernegara.

Desa dapat diumpamakan sebagai slaput dara dan rentan akan kemajuan kebaruan dan pemahahruan hukum terutama menyangkut perekonomian. Ekonomi desa tidak terlepas dari sejarah bangsa Indonesia selama masa penjajahan 3,5 abad menggambarkan eksploitasi sistem kapitalisme liberal atas ekonomi rakyat yang berakibat pada pemiskinan kebaruan dan keterlambatan pembaharuan hukum. Struktur sosial ekonomi yang tidak berkeadilan, membangkitkan tekad luhur proklamasi kemerdekaan, hendak diubah menjadi masyarakat yang adil dan makmur berdasarkan Pancasila: Ketuhanan Yang Maha Esa, Kemanusiaan yang Adil dan Beradab, Persatuan Indonesia, dan Kerakyatan yang dipimpin oleh Hikmat Kebijaksanaan dalam Permusyawaratan/Perwakilan, serta dengan mewujudkan Keadilan Sosial bagi
Seluruh Rakyat Indonesia. ${ }^{29}$ Percepatan ekonomi digital desa dihadapka pada dualistik antara kebaruan dan pembaharuan hukum.

Desa $^{30}$ di Indonesia dijadikan rekayasa "eksperimen" percepatan ekonomi dan pemaksaan dunia digital dalam suasana sistem ekonomi global yang bernaluri pemangsa (predator). Rekayasa pertama berupa percepatan program ekonomi melalui website desa gagal karena tidak sesuai dengan kemampuan masyarakat desa, sedangkan rekayasa kedua dengan cara memberikan kebaruan dan pembaharuan hukum berdasarkan perkembangan jaman dianggap kebablasan karena paham internasional liberalisme dan neoliberalisme makin agresif menguasai ekonomi Indonesia dalam semangat globalisasi yang garang.

Krisis moneter yang menyerang ekonomi Indonesia tahun 1997 merontokkan sektor perbankan-modern yang keropos karena sektor yang kapitalistik terlalu mengandalkan pada modal asing. Utang-utang luar negeri yang makin besar, baik utang pemerintah maupun swasta, makin menyulitkan

\footnotetext{
${ }^{29}$ Pancasila sila pertama sampai sila lima.

${ }^{30}$ Desa diartikan sebagai kesatuan wilayah yang dihuni oleh sejumlah keluarga yang mempunyai sistem pemerintahan sendiri (dikepalai oleh seorang kepala desa); http://kbbi.kata.web.id/?s=de sa, up date 30 Januari 2018.
} 
ekonomi Indonesia karena resep-resep penyehatan ekonomi (hutang, pencabutan subsidi dan privatisasi) dari Dana Moneter Internasional (IMF) tidak saja tidak menguatkan, tetapi justru melemahkan daya tahan ekonomi rakyat. Krisis Moneter juga menciptakan suasana ketergantungan ekonomi Indonesia pada kekuatan kapitalis luar negeri Krisis sosial dan krisis politik yang mengancam keutuhan bangsa karena meledak bersamaan dengan krisis moneter 1997 bertambah parah karena selama lebih dari 3 dekade sistem pemerintahan yang sentralistik telah mematikan daya kreasi daerah dan masyarakat di daerah-daerah. ${ }^{31}$

Desentralisasi dan Otonomi Daerah untuk meningkatkan partisipasi masyarakat daerah dalam pembangunan ekonomi, sosialbudaya, dan politik daerah, menghadapi hambatan dari kepentingankepentingan ekonomi angkuh dan mapan baik di pusat maupun di daerah. Ekonomi Rakyat di daerah-daerah dalam pengembangannya memerlukan dukungan modal, yang selama bertahun-tahun mengarus ke pusat karena sistem perbankan sentralistik. Modal dari daerah makin deras mengalir ke pusat selama krisis moneter.

\footnotetext{
31 Supriyanto, "Memahami Cara Bekerja Sistem Perekonomian" Jurnal Ekonomi \& Pendidikan, Volume 6 Nomor 2, November 2009, 194-195.
}

Produsen dan Konsumen, secara sederhana akan melakukan kegiatan penjualan dan pembelian di pasar yang saling mendukung untuk memenuhi kebutuhan dan kepentingannya masingmasing. Untuk memfasilitasi kegiatan produksi dan kegiatan konsumsi ini secara efektif maka sistem perekonomian memerlukan lembaga perbankan dan lembaga keuangan lainnya seperti pasar modal, lembaga asuransi, lembaga penjamin, pegadaian atau lembaga keuangan mikro yang terdapat di daerah pedesaan.

Pergerakan sektor ekonomi dari produsen perkembangannya dapat diketahui secara tidak langsung dengan memonitor antara lain data perkembangan pemberian fasilitas kredit baru oleh perbankan nasional dan data perkembangan produksi dari berbagai kegiatan sektor ekonomi. Dalam sistem perekonomian sederhana tersebut dalam keadaan normal biasanya akan berjalan dengan sendirinya, tanpa perlu pengaturan yang ketat dari Pemerintah. Pasar dapat mengatur segalanya dengan baik dan sempurna. Pasar seolah-olah dalam sistem perekonomian ini akan bekerja secara otomatis melalui tangan kuat yang 
mengaturnya dari luar, biasa disebut dengan the invisible hand. ${ }^{32}$

Kenyataan di lapangan, mekanisme pasar tidak dapat memberikan jaminan bahwa model sistem perekonomian sederhana ini dapat berjalan dengan sempurna, tanpa distorsi atau kerugian bagi kepentingan masyarakat yang lebih luas. Di banyak negara berkembang umumnya, terdapatnya kenyataan mekanisme pasar bebas yang tetap menghasilkan banyak kekurangan, kejanggalan maupun kecurangan, atau kerugian di pihak konsumen. Dalam jangka panjang sering terjadi kecenderungan pengelompokan produsen tertentu yang menguasai pangsa pasar secara dominan. Guna menetralisir atau mengurangi kemungkinan kerugian tersebut, maka diperlukan peran pemerintah atau Lembaga Publik yang berfungsi melakukan koreksi-koreksi atas sistem pasar yang tidak efisien dan tidak adil.

Dalam sistem perekonomian yang terbuka, kita melihat kemungkinan dari produsen untuk melakukan kegiatan ekspor barang dan produk dagangannya ke negara lain atau sebaliknya melakukan

${ }^{32}$ Sarip dan Diana Fitriana, Mengawal Peraturan Daerah dan Meningkatkan Pendapatan Asli Daerah Melalui Pajak dan Retribusi Daerah, Cv. Confident, (Cirebon; 2018), 27-28. kegiatan impor keperluan bahan mentah dan bahan penolong maupun komponen mesin atau barang jadi dari luar negara kita. Dalam model terbuka ini jasa perbankan dan lembaga keuangan dapat juga berasal dari sektor luar negeri, seperti kreditor-kreditor swasta luar negeri dan lembaga keuangan internasional. ${ }^{33}$

Di era kapitalisme seperti saat ini. setiap manusia yang tinggal di atas muka bumi ini sudah bisa melihat, memahami dan merasakan bagaimana dampak yang ditimbulkan oleh kapitalisme global. Mereka akan langsung bisa menjawab ketika ditanya tentang wajah ekonomi yang berlangsung saat ini, walaupun tidak bisa memberikan istilah yang tepat untuknya. Setiap orang langsung dapat mendeteksi bahwa ada ketidakberesan dari tata ekonomi yang berlangsung saat ini. Wajah ekonomi saat ini terus berjalan menuju kepada dua kutub yang sangat berlawanan. Satu kutub telah membawa mereka yang kaya menjadi semakin kaya, sedangkan kutub yang lain terus menyeret mereka yang miskin menjadi semakin miskin dengan jumlah yang terus membengkak.

Oleh karena itu salah satu solusi dalam mencari bentuk Sistem Ekonomi

33 
Nasional Indonesia adalah Sistem Ekonomi Kerakyatan yaitu ekonomi berasas kekeluargaan yang demokratis dan bermoral dengan pemihakan pada sektor ekonomi rakyat. Pemihakan dan perlindungan pada ekonomi rakyat merupakan strategi memampukan dan memberdayakan pelaku-pelaku ekonomi rakyat yang sejak zaman penjajahan dan setengah abad Indonesia Merdeka selalu dalam posisi tidak berdaya. Untuk itu prasyarat sistem ekonomi nasional yang harus ada berkeadilan sosial adalah berdaulat di bidang politik, mandiri di bidang ekonomi, dan berkepribadian di bidang budaya. Percepatan ekonomi digital dapat dilakukan dengan selama tidak merusak slaput dara desa. Sebab, apabila merusak slaput dara desa apa yang diharapak mustahil akan terwujud sebagaimana rekayasa hukum terhadap kebaruan dan pembaharuan di desa.

\section{Penutup}

Negara hukum berkenaan dengan kebaruan dan pembaharuan hukum di desa berkenaan dengan percepatan ekonomi digital dianggap sebagai saluran, sarana, sejenis selaput yang bisa ditembus tanpa mengganggu atau merusak selaput.

Kebaruan terhadap percepatan desa dalam bidang ekonomi terkadang tidak sesuai harapan. Untuk mengantisipasi pemerintah harus melakukan pembaharuan hukum. Adapaun pembaharuan hukum yang ideal jangan sampai merusak tatanan perekonomian dan keadaan masayrakat yang sudah tertata.

\section{E. Daftar Pustaka}

Azhari, (1995). Negara Hukum Indonesia, Analisis Normatif Tentang UnsurUnsurnya, Jakarta: Universitas Indonesia Press,

Carter. Apcil, (1985). Otoritas dan Demokrasi, Jakarta: Rajawali Press, Friedman Lawrence F., (1998). Terjemahan, The Legal System A Social Science Persepective, New York: Russel Sage Foundation.

Kemendes, (2018), Petunjuk Teknis Lomba Penulisan Artikel Dana Desa Tahun 2018.

Mahfud MD.Moh. (2014), Politik Hukum di Indonesia. Jakarta: RajaGrafindo Persada,

Rahardjo Satjipto, (2010), Pemanfaatan $\begin{array}{lrr}\text { Ilmu-Ilmu } & \text { Sosial } & \text { Bagi } \\ \text { Pengembangan } & \text { Ilmu } & \text { Hukum, }\end{array}$

Yogyakarta: GentaPublishing, Asshiddiqie,Jimly. (2006). Hukum Tata Negara dan Pilar-Pilar Pilar Demokrasi, Serpihan Pemikiran 
Hukum, Media dan HAM, Jakarta:

Konstitusi Perss,

Wahyono,Padmo, (1986), Pidato

Pengukuhan sebagai Guru Besar

Fakultas Hukum UI tanngal 17

November 1979. Seperti dikutip

dalam bukunya sendiri, Indonesia

Negara berdasarkan Atas Hukum,

Jakarta: Ghalia Indonesia.

Triwulan Tutik, Titik. (2006), Pokok-

pokok Hukum Tata Negara, Jakarta:

Prestasi Pustaka

Fadli Moh. dk, 2011, Pembentukan

Peraturan Desa Partisipatif,

Malang: Brawijaya Press.

Sarip dan Diana Fitriana, (2018).

Mengawal Peraturan Daerah dan

Meningkatkan Pendapatan Asli

Daerah Melalui Pajak dan Retribusi

Daerah, Cirebon: Cv. Confident.

Sarip, (2018), Hukum Tata Negara

Materil, Cirebon: Elsi Pro.

Sartono Kartodirdjo, (1984). Ratu Adil,

Jakarta: Sinar Harapan.

Tahmid, Khairuddin. (2011), Dekonstruksi

Politik Hukum Otonomi Desa Dalam

Peraturan Perundang-undangan Di

Indonesia, Yogyakarta: ringkasan

disertasi progam doktor UII.

Jurnal Website
C.T. Adhikara, Siapa Konsumen Kita?: Analisis Perubahan Konsumen di Era Ekonomi Baru, Jurnal The WINNER, Volume. 6 No.2, September 2005,

Krishna Djaya Darumurti, "Karakter Ilmu Hukum: Pendekatan Fungsional Dalam Kaitan dengan Pendidikan Hukum". Jurnal REFLEKSI HUKUM, Volume 1, Nomor 2, 2016.

PS. Purwanto dan Heryandi Norman, Aspek Medikolegal Pemeriksaan Selaput Dara Pada Korban Dugaan Perkosaan di RS. Dr. Hasan Sadikin Bandung, Perhimpunan Dokter Forensik Indonesia, Proseding Pertemuan Tahunan di Pekanbaru tanggal 15-16 Juli Tahun 2017.

Sarip, Pola Pikir Kelas Elit Dalam Perumusan Perundang-Undangan di Indonesia, Jurnal De Jure Muhammadiyah Cirebon Volume 1, Nomor 1, 2017.

Sayuti, "Konsep Rechts Staat dalam Negara Hukum Indonesia (Analisis Terhadap Pendapat Azhari)", Jurnal Kajian Ekonomi Islam dan Kemasyarakatan NALAR FIQH, Volume 4. Nomor 2. 2011.

Tim Penyusun kamus Pusat Pembianaan dan Pengembangan Bahasa, Kamus 
Besar Bahasa Indonesia Cet. VII,

Balai Pustaka, (Jakarta: 1995),

Yusnani Hasyimzoem, "Dinamika Hukum

Pemerintahan Desa”, Jurnal Fiat

Justitia Ilmu Hukum, Volume 8,

Nomor 5.

Supriyanto, Memahami Cara Bekerja

Sistem Perekonomian Jurnal

Ekonomi \& Pendidikan, Volume 6

Nomor 2, November 2009 hlm 194-

195.

Perundang-undangan

Undang-Undang Nomor 32 tahun 2004 tentang Pemerintahan Daerah yang menggantikan Undang-Undang Nomor 22 tahun 1999.

Undang-Undang Republik Indonesia Nomor 19 Tahun 2016 tentang Perubahan Atas Undang-Undang Nomor 11 Tahun 2008 tentang Informasi dan Transaksi Elektronik.

Undang-Undang Nomor 6 Tahun 2014 tentang Desa Lembaran Negara Nomor 7 dan Tambahan Lembaran Negara Nomor 5495.

Putusan Mahkamah Konstitusi Nomor 50/PUU-VI/2008, Nomor 2/PUUVII/2009, Nomor 5/PUU-VIII/2010, dan Nomor 20/PUU-XIV/2016.
World Wide Web

http://kbbi.kata.web.id/?s=baru, up date 21 Januari 2017.

Fokky Fuad dalam, http://uai.ac.id/2011/04/13/hukumsebagai-rekayasa-sosial-kesalahanpemahaman-atas-pemikiran-roscoepound/ Up date 20 Januari 2018. http://bpmpd.ntprov.go.id/index.php/2016/ 08/03/website-gratis-1-tahun-darikementrian-kominfo/ Up Date 29 Januari 2018.

http://file.upi.edu/Direktori/FIP/JUR._KU RIKULUM_DAN_TEK._PENDIDI KAN/196610191991021-

RUDI_SUSILANA/PM3-ModulPenelitian_5.pdf , Up Date 2 Mei 2018. 